\title{
Implementasi Model Pembelajaran Kooperatif Tipe Numbered Head Together (Nht) Untuk Meningkatkan Aktivitas Dan Hasil Belajar Teknik Passing Kaki Bagian Dalam Permainan Sepak Bola
}

Muh. Iqma Tullah*

${ }^{1}$ Universitas Pendidikan Ganesha

\section{ART I CLE IN F O}

Article history:

Received January 21, 2021

Revised February 03, 2021

Accepted April 08, 2021

Available online May 25, 2021

\section{Kata Kunci:}

Pendekatan saintifik,

kooperatif tipe NHT, hasil

belajar, teknik dasar passing

kaki bagian dalam

Keywords:

Scientific approach, NHT type cooperation, learning

outcomes, basic techniques of passing the inner foot disimpulkan bahwa hasil belajar teknik dasar passing kaki bagian dalam meningkat melalui implementasi model
pembelajaran kooperatif tipe NHT pada peserta didik kelas X D AKL SMK Negeri 1 Singaraja tahun pelajaran disimpulkan bahwa hasil belajar teknik dasar passing kaki bagian dalam meningkat melalui implementasi model
pembelajaran kooperatif tipe NHT pada peserta didik kelas X D AKL SMK Negeri 1 Singaraja tahun pelajaran 2018/2019. Disarankan kepada guru penjasorkes untuk mengaplikasikan implementasi model pembelajaran kooperatif tipe NHT karena dapat meningkatkan hasil belajar teknik dasar passing kaki bagian dalam.

A B S T R A K

Penelitian ini adalah penelitian tindakan kelas yang dilaksanakan dalam dua siklus, yang terdiri dari rencana tindakan, pelaksanaan tindakan, observasi atau evaluasi dan refleksi. Subjek penelitian peserta didik kelas X D AKL SMK Negeri 1 Singaraja, berjumlah 32 orang dengan rincian 10 orang putra dan 22 orang putri. Data dianalisis menggunakan statistik deskriptif. Berdasarkan hasil observasi awal yang dilakukan peneliti pada hari Selasa, 21 Agustus 2018 di kelas X D AKL SMK Negeri 1 Singaraja tahun pelajaran 2018/2019, aktivitas belajar 32 peserta didik (22 peserta didik perempuan dan 10 peserta didik laki-laki) pada materi teknik dasar passing sepak bola kaki bagian dalam yang diperoleh pada saat observasi tergolong cukup aktif. Dapat dilihat dari komponen aktivitas belajar peserta didik yang terdiri dari kegiatan visual, lisan, mendengarkan, metrik, mental dan emosional. Berdasarkan hasil pengamatan dari keenam komponen aktivitas tersebut didapatkan hasil persentase sebagai berikut: Peserta didik pada kategori sangat aktif tidak ada $(0 \%), 14$ orang $(46,7 \%)$ berada dalam kategori tingkat aktivitas yang aktif, 12 orang $(33,3 \%)$ berada dalam kategori tingkat aktivitas yang cukup aktif, 6 orang $(20 \%)$ berada dalam kategori tingkat aktivitas yang kurang aktif, dan tidak ada orang $(0 \%)$ berada dalam kategori tingkat aktivitas yang sangat kurang aktif, dengan persentase ketuntasan 14 orang $(46,7 \%)$ tuntas dan 18 orang $(53,3 \%)$ tidak tuntas. Berdasarkan hasil analisis data dan pembahasan dapat

\begin{abstract}
A B S TR A C T
This study aims to improve the learning outcomes of part passing foot techniques in soccer games through the implementation of NHT type cooperative learning models for students of class X D AKL of SMK Negeri 1 Singaraja in the 2018/2019 school year. This research is a classroom action research conducted in two cycles, consisting of action plans, action implementation, observation or evaluation and reflection. The subjects of the study were students of class X D AKL at SMK Negeri 1 Singaraja, totaling 32 people with details of 10 sons and 22 daughters. Data were analyzed using descriptive statistics. Based on the results of preliminary observations conducted by researchers on Tuesday, August 21, 2018 in class XD AKL SMK Negeri 1 Singaraja academic year 2018/2019, learning activities were 32 students (22 female students and 10 male students) on basic technical materials inner foot soccer passes obtained during observation are quite active. It can be seen from the components of students' learning activities which consist of visual, verbal, listening, metric, mental and emotional activities. Based on the observations of the six components of the activity, the following percentage results are obtained: Students in the very active category were absent (0\%), 14 people (46.7\%) were in the active activity level category, 12 people (33.3\%) were in the category of active activity level, 6 people (20\%) are in the category of activity level that is less active, and no person (0\%) is in the category of activity level that is very less active, with a percentage of completeness of 14 people (46.7\%) completed and 18 people (53.3\%) not complete. Based on the results of data analysis and discussion, it can be concluded that the learning outcomes of the basic passing foot techniques are increased through the implementation of NHT type cooperative learning models for students of class X D AKL of SMK Negeri 1 Singaraja in the 2018/2019 school year. It is suggested to the physical education teacher to apply the implementation of the NHT type cooperative learning model because it can improve the learning outcomes of the basic techniques of passing the inner foot.
\end{abstract}

\section{Pendahuluan}

Pendidikan merupakan landasan dalam menciptakan generasi penerus yang berkualitas. Kualitas sumber daya manusia sangat berpengaruh besar pada perkembangan ilmu pengetahuan di segala bidang. Peningkatan kualitas sumber daya manusia harus dimulai sejak dini. Untuk meningkatkan kualitas sumber daya manusia tidak lepas dari peningkatan mutu di bidang pendidikan. Melalui bidang pendidikan 
inilah generasi generasi muda mulai diberi dasar yang kuat. Salah satu unsur penunjang dalam dunia pendidikan ialah para pendidik (Hakim, Sunarto and Totalia, 2016). Dalam perspektif filosofis, pendidikan adalah usaha membantu manusia memanusiakan manusia2 . Artinya, manusia yang mendapat pendidikan akan lebih baik dalam menjalani kehidupannya dibanding manusia yang tidak mendapatkan pendidikan. Pendidikan pada hakikatnya berlangsung dalam suatu proses. Proses itu berupa transformasi nilai-nilai pengetahuan, teknologi dan keterampilan. Penerima proses adalah siswa/mahasiswa yang sedang tumbuh dan berkembang menuju arah pendewasaan kepribadian dan penguasaan pengetahuan. Selain itu, pendidikan merupakan proses budaya untuk meningkatkan harkat dan martabat manusia yang diperoleh melalui proses yang panjang dan berlangsung sepanjang kehidupan (Saleh, 2013). Salah satu masalah yang dihadapi dalam dunia pendidikan kita adalah masih lemahnya dalam penerapan proses pembelajaran. Guru masih mendominasi, sedangkan yang diharapkan pendidikan sekarang adalah siswa yang harus mendominasi. Guru yang setiap hari berhadapan dengan siswa masih belum memahami tentang karakteristik anak didik. Apabila seorang guru telah mampu memahami karakteristik siswa maka akan mudah menerapkan strategi yang akan dilaksanakan dalam proses pembelajaran. Strategi adalah suatu siasat yang diupayakan oleh seorang guru sebelum melakukan tugas pengajaran (San Adam, 1988 : 40). Menurut Wina Sanjaya (2008 : 25) Undangundang No. 20 tahun 2003 tentang Sistem Pendidikan Nasional menyatakan bahwa pendidikan adalah usaha sadar dan terencana untuk mewujudkan suasana belajar dan proses pembelajaran agar peserta didik secara aktif mengembangkan prestasi dirinya untk memiliki kekuatan spiritual keagamaan, pengendalian diri, kepribadian, kecerdasan, akhlak mulia, serta keterampilan yang diperlukan dirinya masyarakat bangsa dan Negara (Wiyasa, 2013).

Sepak bola merupakan salah satu unsur dari pendidikan jasmani yang juga merupakan komponenkomponen dari pendidikan secara keseluruhan yang mengutamakan aktivitas jasmani serta unsur menyenangkan dan banyak digemari oleh seluruh lapisan masyarakat (Irianto, 2011). Sepak bola menurut Susanto \& Lismadiana, (2016) adalah permainan beregu yang dimainkan oleh dua buah regu, masingmasing tim terdiri sebelas pemain, dengan tujuan mencetak gol sebanyakbanyaknya ke gawang lawan dan berusaha menggagalkan serangan lawan untuk menjaga agar gawangnya tidak kemasukan bola (Atiq and Selamet Budiyanto, 2020).

Sepak bola adalah wadah di mana orang dari berbagai latar-belakang etnis bertemu. Terkadang pertandingan sepak bola berakhir dengan pertengkaran antar orang yang berbeda latar belakang dan suporter. Walaupun demikian, sepak bola tetap menjadi meeting point yang mendapat perhatian oleh masyarakat (Colombijn, 2010: xix-xx). Sepak bola menjadi kultur di berbagai negara dan mampu menyedot perhatian massa dan dapat menghadirkan suguhan olahraga yang tidak hanya bernilai olahraga saja (Aji, 2013).

Sepak bola memang tidak terlepas dari peranan kolonialisme Belanda. Terbentuknya klub-klub sepak bola dari orang Eropa (Belanda) di Surabaya merupakan hal penting mendorong pertumbuhan klub-klub yang ada baik dari Pribumi, Tionghoa, kemudian dari orang Arab yang turut dalam perkembangan sepak bola. Perkembangan olahraga klub sepak bola dari orang Arab merupakan suatu perspektif baru tentang suatu kajian tentang sepak bola, dimana orang Arab juga yang mempunyai peranan penting dalam perjalanan sepak bola yang ada di Surabaya, tidak terlepas mereka juga sangat berperan besar dalam sektor sosial, ekonomi, dan budaya (Hidayat and Kusuma, 2013). Hingga kini, tidak ada olahraga yang mendapatkan sambutan paling meriah dan gegap gempita dari masyarakat di berbagai negara dunia selain sepak bola. Untuk itulah tidak sedikit analisa yang meyakini bahwa sepak bola bukan sekedar olahraga, tapi sebuah olahraga yang menimbulkan perang, revolusi, dan menjadi perhatian mafia dan para diktator. Sepak bola modern kini berkembang dari masa ke masa. Banyak sekali aspek yang di pengaruhi atau mempengaruhi dalam proses berkembangnya olah raga ini diantarannya aspek sosial, ekonomi, politik dan hiburan. Indonesia merupakan salah satu Negara yang memiliki antusias yang tinggi terhadap olahraga sepak bola. Hampir seluruh lapisan masyarakat menggemari olahraga ini. Terbukti dengan menjamurnya klub-klub sepak bola di berbagai daerah di Indonesia (Prawira and Tribinuka, 2016).

Untuk meningkatkan kemampuan dalam permainan sepakbola, khusus dalam teknik dasar passing bola yang diajarkan di sekolah perlu adanya sebuah metode pembelajaran yang lebih baik dan tepat. Namun bentuk metode pembelajaran yang dilakukan harus spesifik dan lebih mengarah, agar dapat menunjang peningkatan kemampuan passing bola dalam permainan sepakbola. Untuk itu perlu adanya metode pembelajaran yang dapat memberikan peningkatan terhadap teknik passing bola dalam permainan sepakbola, sehingga memberikan penerapan langsung baik dalam penilaian maupun pelaksanaannya di dalam bermain bagi siswa yang berminat untuk mengeluti cabang olahraga sepakbola. Metode pembelajaran yang dimaksud adalah metode bermain berpasangan. Metode bermain berpasangan merupakan cara melakukan teknik passing bola langsung sambil memiliki rintangan atau halangan yang dapat membuat siswa merasa terbebani. (Budiman Agung, 2018). 
Kurikulum terus disesuaikan, berbagai pendekatan dan metode pembelajarandisempurnakan, pembelajaran tambahan jam ekstra terus dilakukan, namun hasil belajar pendidikan jasmani, olahraga dan kesehatan (PJOK) belum sesuai dengan harapan. Salah satu penyebabnya adalah pelaksanaan pembelajaran mata pelajaran PJOK sering mengalami masalah. Bagi siswa masalah sering dialami karena sebagian besar siswa sudah beranggapan bahwa PJOK merupakan pelajaran yang memerlukan tenaga besar, perlu kekuatan tubuh yang cukup dan memerlukan keterampilan khusus disamping itu kebanyakan siswa di setiap jenjang pendidikan masih banyak berpandangan bahwa PJOK merupakan mata pelajaran yang sulit dan sering menimbulkan masalah dalam belajar. Pada pelajaran PJOK terutama di SMK, siswa cenderung kurang aktif untuk berpartisipasi dalam proses pembelajaran, hal ini terbukti dari aktvitas dan hasil belajar gerak yang diperoleh siswa kurang memuaskan atau belum memenuhi sasaran yang ditunjukkan dengan belum dikuasainya teknik-teknik gerak yang diajarkan. Siswa cenderung menyepelekan pelajarn PJOK, sebab mereka lebih terkonsentrasi pada mata pelajaran yang diujikan pada ujian nasional.

Berdasarkan hasil observasi awal yang dilakukan peneliti pada hari Selasa, 21 Agustus 2018 di kelas X D AKL SMK Negeri 1 Singaraja tahun pelajaran 2018/2019, aktivitas belajar 32 peserta didik (22 peserta didik perempuan dan 10 peserta didik laki-laki) pada materi teknik dasar passing sepak bola kaki bagian dalam yang diperoleh pada saat observasi tergolong cukup aktif. Dapat dilihat dari komponen aktivitas belajar peserta didik yang terdiri dari kegiatan visual, lisan, mendengarkan, metrik, mental dan emosional. Berdasarkan hasil pengamatan dari keenam komponen aktivitas tersebut didapatkan hasil persentase sebagai berikut: Peserta didik pada kategori sangat aktif tidak ada (0\%), 14 orang $(46,7 \%)$ berada dalam kategori tingkat aktivitas yang aktif, 12 orang $(33,3 \%)$ berada dalam kategori tingkat aktivitas yang cukup aktif, 6 orang (20\%) berada dalam kategori tingkat aktivitas yang kurang aktif, dan tidak ada orang $(0 \%)$ berada dalam kategori tingkat aktivitas yang sangat kurang aktif, dengan persentase ketuntasan 14 orang $(46,7 \%)$ tuntas dan 18 orang $(53,3 \%)$ tidak tuntas. Berdasarkan data di atas, maka peneliti bisa mengetahui rata-rata klasikal aktivitas belajar teknik dasar passing kaki bagian dalam sebesar 6,2 yang tergolong dalam kategori cukup aktif. Sehingga dapat diketahui berapa banyak peserta didik yang tuntas dan peserta didik tidak tuntas.

Peserta didik pada kategori sangat aktif tidak ada $(0 \%), 14$ orang $(46,7 \%)$ berada dalam kategori tingkat aktivitas yang aktif, 12 orang $(33,3 \%)$ berada dalam kategori tingkat aktivitas yang cukup aktif, 6 orang $(20 \%)$ berada dalam kategori tingkat aktivitas yang kurang aktif, dan tidak ada orang $(0 \%)$ berada dalam kategori tingkat aktivitas yang sangat kurang aktif, dengan persentase ketuntasan 14 orang $(46,7 \%)$ tuntas dan 18 orang $(53,3 \%)$ tidak tuntas. Berdasarkan data di atas, maka peneliti bisa mengetahui rata-rata klasikal aktivitas belajar teknik dasar passing kaki bagian dalam sebesar 6,2 yang tergolong dalam kategori cukup aktif. Sehingga dapat diketahui berapa banyak peserta didik yang tuntas dan peserta didik tidak tuntas. Jika dilihat dari hasil observasi, ketuntasan hasil belajar untuk aspek pengetahuan, peserta didik yang berada pada kategori baik 8 orang (20\%), dan pada kategori cukup baik 24 orang (80\%). Jadi jumlah siswa yang tuntas dalam Teknik Dasar Passing Kaki Bagian Dalamaspek pengetahuan secara klasikal yaitu 8 orang $(20 \%)$ tuntas dan 24 orang $(80 \%)$ tidak tuntas, dengan presentase nilai rata-rata hasil belajar secara klasikal yaitu $80 \%$ yang berada pada kategori tidak tuntas. Dengan menganalisa data hasil belajar kompetensi pengetahuan peserta didik secara keseluruhan terlihat belum memenuhi sasaran, karena belum memenuhi standar kriteria ketuntasan minimal (KKM) sekolah untuk mata pelajaran PJOK sebesar $81 \%$ ketuntasan klasikal. Permasalahan yang muncul pada aspek pengetahuan adalah kurangnya pemahaman peserta didik mengenai teknik dasar passing kaki bagian dalam, hal ini disebabkan oleh kurangnya perhatian peserta didik pada saat guru menjelaskan dan pembelajaran masih dominan guru yang lebih aktif.

Jadi jika dilihat dari rata-rata aktivitas dan hasil belajar teknik dasar passing kaki bagian dalam di atas dapat disimpulkan bahwa, aktivitas dan hasil belajar teknik dasar passing kaki bagian dalam pada kelas X D AKL SMK Negeri 1 Singaraja tidak tuntas. Hal ini disebabkan implementasi model pembelajaran yang belum efektif terhadap materi yang disajikan. Model pembelajaran yang diimplementasikan belum melibatkan atau merangsang peserta didik untuk lebih aktif dan kreatif selama proses pembelajaran berlangsung. Berdasarkan permasalahan di atas, peneliti mencoba memberikan salah satu alternatif pemecahan masalah yaitu dengan menerapkan model pembelajaran kooperatif tipe Numbered Head Together (NHT) dalam pembelajaran PJOK pada materi teknik dasar passing kaki bagian dalam. Ketertarikan peneliti menerapkan model pembelajaran kooperatif tipe NHT ini karena (1) model pembelajaran kooperatif dengan tipe NHT adalah model pembelajaran yang sederhana, sehingga model pembelajaran kooperatif ini cocok diterapkan pada peserta didik kelas X D AKL SMK Negeri 1 Singaraja yang belum pernah melakukan pembelajaran kooperatif tipe NHT, (2) pada model pembelajaran ini peserta didik lebih banyak mempunyai kesempatan diskusi kelompok, masing-masing peserta didik memberikan partisipasinya secara maksimal dan setiap peserta didik mempunyai tanggung jawab perseorangan untuk menguasai materi dengan sebaik-baiknya, (3) model pembelajaran kooperatif 
dengan tipe NHT mengajak peserta didik untuk belajar aktif dan berani dalam mengeluarkan pendapat dalam diskusi kelompok. Apabila ada suatu konsep yang belum dimengerti dan dipahaminya, peserta didik dapat saling isi mengisi dengan peserta didik lain, saling bertukar pikiran sehingga diharapkan konsep yang dimiliki peserta didik benar-benar dapat dipahami dengan baik. Suasana belajar.

\section{Metode}

\section{Rancangan Penelitian}

Penelitian Penelitian ini adalah penelitian tindakan kelas (PTK) karena bertujuan memperbaiki kualitas pembelajaran yang bermuara pada peningkatan kualitas kinerja guru dan peningkatan aktivitas serta hasil belajar siswa. "Menurut Arikunto, dkk (2006: 3), menyatakan bahwa, "PTK merupakan suatu pencermatan terhadap kegiatan akan lebih kondusif, yang akhirnya berpengaruh terhadap aktivitas dan hasil belajar. Pemilihan tentang model pembelajaran NHT ini juga dikuatkan oleh hasil penelitian dari peneliti-peneliti sebelumnya diantaranya (1) Penelitian yang dilakukan oleh Sanjaya, I.P.E.Y (2013:123) dalam skripsinya yang menyimpulkan motivasi dan hasil belajar teknik Lompat jauh gaya menggantungmeningka melalui penerapan model pembelajaran kooperatif tipe NHT pada peserta didik kelas X.5 SMA Negeri 1 Negara tahun pelajaran 2012/2013, (2) Penelitian yang dilakukan oleh Bawa, I.M.L (2012:116) dalam skripsinya yang menyimpulkan aktivitas dan hasil belajar teknik dasar passing sepak bola meningkat melalui penerapan model pembelajaran kooperatif tipe NHT pada peserta didik kelas X.1 SMK Negeri 2 Singaraja tahun pelajaran 2011/2012, Penelitian ini dilaksanakan 2 (dua) siklus, di mana masing- masing siklus terdiri dari 2 (dua) kali pertemuan. Pada pertemuan pertama diberikan pembelajaran secara penuh, terkait materi yang diberikan, sedangkan pada pertemuan kedua diberikan pengulangan untuk memantapkan penguasaan materi yang sebelumnya telah diberikan pada pertemuan pertama, dan sekaligus pengambilan data hasil belajar teknik dasar passing kaki bagian dalam dengan dievaluator oleh guru mengajar Penjasorkes. Pada siklus I materi yang diberikan adalah pembelajaran teknik dasar passing kaki bagian dalam, sedangkan pada siklus II materi yang diberikan materi pemantapan dari pembelajaran teknik dasar passing kaki bagian dalam jika terjadi ketidak tuntasan di siklus I. Adapun tujuan penelitian yang ingin dicapai adalah:

Untuk meningkatkan aktivitas belajar dan hasil belajar teknik dasar passing kaki bagian dalam melalui implementasi model pembelajaran kooperatif tipe NHT pada siswa kelas X D AKL SMK Negeri 1 Singaraja tahun pelajaran 2018/2019.

\section{Hasil Dan Pembahasan}

Berdasarkan hasil observasi awal yang dilakukan peneliti pada hari Selasa, 21 Agustus 2018 di kelas X D AKL SMK Negeri 1 Singaraja tahun pelajaran 2018/2019, aktivitas belajar 32 peserta didik (22 peserta didik perempuan dan 10 peserta didik laki-laki) pada materi teknik dasar passing sepak bola kaki bagian dalam yang diperoleh pada saat observasi tergolong cukup aktif. Peserta didik pada kategori sangat aktif tidak ada $(0 \%), 14$ orang $(46,7 \%)$ berada dalam kategori tingkat aktivitas yang aktif, 12 orang $(33,3 \%)$ berada dalam kategori tingkat aktivitas yang cukup aktif, 6 orang $(20 \%)$ berada dalam kategori tingkat aktivitas yang kurang aktif, dan tidak ada orang $(0 \%)$ berada dalam kategori tingkat aktivitas yang sangat kurang aktif, dengan persentase ketuntasan 14 orang (46,7\%) tuntas dan 18 orang (53,3\%) tidak tuntas. Berdasarkan data di atas, maka peneliti bisa mengetahui rata-rata klasikal aktivitas belajar teknik dasar passing kaki bagian dalam sebesar 6,2 yang tergolong dalam kategori cukup aktif. Sehingga dapat diketahui berapa banyak peserta didik yang tuntas dan peserta didik tidak tuntas.

Tabel 1. Data Aktivitas Belajar teknik dasar passing kaki bagian dalam

\begin{tabular}{|c|c|c|c|c|c|}
\hline No & Kriteria & $\begin{array}{r}\text { Jumlah } \\
\text { Peserta } \\
\text { Dididk }\end{array}$ & Persentase & Kategori & Keterangan \\
\hline 1 & $X \bar{?}$ & - & - & Sangat aktif & $\begin{array}{lr}25 & \text { Orang } \\
\text { Peserta } & \text { Didik }\end{array}$ \\
\hline 2 & 7国 $\overline{X<9}$ & 25 & $78 \%$ & Aktif & Aktif (78\%) \\
\hline 3 & 5 目 $\overline{X<7}$ & 7 & $22 \%$ & Cukup Aktif & $\begin{array}{ll}7 & \text { Orang } \\
\text { Peserta } & \text { Didik }\end{array}$ \\
\hline 4 & 3 目 $\overline{X<5}$ & - & - & Kurang Aktif & Tidak Aktif(22\%) \\
\hline 5 & $x \overline{<3}$ & - & - & $\begin{array}{l}\text { Sangat Kurang } \\
\text { Aktif }\end{array}$ & \\
\hline
\end{tabular}




\begin{tabular}{|c|c|c|}
\hline Total & 32 & $\begin{array}{l}32 \text { Peserta } \\
\text { Dididk (100\%) }\end{array}$ \\
\hline
\end{tabular}

Dari tabel 1 di atas dapat dilihat bahwa, peserta didik yang berada pada kategori sangat aktif tidak ada, kategori aktif 25 orang (78\%), kategori cukup aktif 7 orang.

Table 2. Ketuntasan Hasil Belajar sepak bola teknik dasar passing kaki bagian dalam Pada Observasi Awal

\begin{tabular}{|c|c|c|c|c|c|}
\hline No & $\begin{array}{c}\text { Jumlah } \\
\text { Peserta } \\
\text { Didik } \\
\end{array}$ & Kriteria & Predikat & Presentase (\%) & Keterangan \\
\hline 1 & 6 & Sangat Baik & A & $18,75 \%$ & \multirow{5}{*}{$\begin{array}{l}27 \text { orang } \\
(84,375 \%) \text { tuntas } \\
5 \text { orang } \\
(15,625) \text { belum } \\
\text { tuntas }\end{array}$} \\
\hline 2 & 21 & Baik & B & $65,625 \%$ & \\
\hline 3 & 5 & Cukup & $\mathrm{C}$ & $15,625 \%$ & \\
\hline 4 & - & Kurang & $\mathrm{D}$ & - & \\
\hline Jumlah & 32 & & & $100 \%$ & \\
\hline
\end{tabular}

Berdasarkan tabel 4.2, hasil belajar aspek pengetahuan pada siklus I dengan materi teknik dasar passing kaki bagian dalam, diperoleh data hasil belajar dengan kategori individu sebagai berikut, 6 orang kategori sangat baik $(18,75 \%), 21$ orang peserta didik (65,625\%) memperoleh nilai dengan kategori baik, 5 orang peserta didik $(15,625 \%)$ memperoleh nlai dengan kategori cukup, dan 0 orang peserta didik $(0 \%)$ memperoleh nilai dengan kategori kurang.

Tabel 3. Data Aktivitas Belajar sepak bola teknik dasar passing kaki bagian dalam Pada Siklus I.

\begin{tabular}{|c|c|c|c|c|c|}
\hline No & $\begin{array}{c}\text { Jumlah } \\
\text { Peserta } \\
\text { Didik }\end{array}$ & Kriteria & Predikat & $\begin{array}{c}\text { Presentase } \\
(\%)\end{array}$ & Keterangan \\
\hline 1 & 10 & Sangat Baik & A & $31,25 \%$ & 26 orang \\
\hline 2 & 16 & Baik & B & $50,00 \%$ & $(81,25 \%)$ tuntas \\
\hline 3 & 6 & Cukup & $\mathrm{C}$ & $18,75 \%$ & 6 orang \\
\hline 4 & - & Kurang & - & & $(18,75)$ belum tuntas \\
\hline Jumlah & 32 & & & $100 \%$ & \\
\hline
\end{tabular}

Berdasarkan tabel 4.4, hasil belajar aspek keterampilan pada siklus I dengan materi teknik dasar passing kaki bagian dalam, diperoleh data hasil belajar dengan kategori individu sebagai berikut, 10 orang kategori sangat baik $(31,25 \%), 16$ orang $(50,00 \%)$ memperoleh nilai dengan kategori baik, 6 orang $(18,75 \%)$ memperoleh nilai dengan kategori cukup, dan tidak ada peserta didik yang memperoleh nilai dengan kategori kurang.

Tabel 4. Data Aktivitas Belajar sepak bola passing kaki bagian dalam padaSiklus II

\begin{tabular}{|c|c|c|c|c|c|}
\hline No & Kriteria & $\begin{array}{c}\text { Jumlah } \\
\text { Peserta } \\
\text { Dididk }\end{array}$ & Persentase & Kategori & Keterangan \\
\hline & & & & & $2 \quad$ Orang \\
\hline \multirow[t]{2}{*}{1} & $X \overline{\text { 百9 }}$ & 2 & $6,25 \%$ & Sangat aktif & $\begin{array}{l}\text { Peserta Didik } \\
\text { sangat Aktif } \\
(6,25 \%)\end{array}$ \\
\hline & & & & & $28 \quad$ Orang \\
\hline \multirow[t]{2}{*}{2} & 7 回 $\bar{X}<9$ & 28 & $87,5 \%$ & Aktif & $\begin{array}{l}\text { Peserta Didik } \\
\text { Aktif }(87,5 \%)\end{array}$ \\
\hline & & & & & 2 Orang \\
\hline 3 & & 2 & $6,25 \%$ & Cukup Aktif & Peserta Didik \\
\hline & 5 目 $\bar{X}<7$ & & & & $\begin{array}{l}\text { cukup Aktif } \\
(6,25 \%)\end{array}$ \\
\hline 4 & 3 ? $\bar{X}<5$ & - & - & Kurang Aktif & \\
\hline 5 & $x \overline{<3}$ & - & - & $\begin{array}{l}\text { Sangat Kurang } \\
\text { Aktif }\end{array}$ & \\
\hline
\end{tabular}

Total

32

$100 \%$

32 Peserta Didik (100\%)

Dari tabel 4.11 di atas dapat dilihat bahwa, peserta didik yang berada pada kategori sangat aktif 2 orang $(6,25 \%)$, kategori aktif 28 orang $(87,5 \%)$, kategori cukup aktif 2 orang $(6,25 \%)$, dan sangat kurang 
aktif. Dari hasil analisis data diatas maka dapat dikatakan bahwa implementasi model pembelajaran NHT cukup efektif untuk meningkatkan aktivitas belajar teknik dasar passing kaki bagian dalam, hal ini dapat dilihat dari persentase ketuntasan belajar yang mencapai 93,7\% (30 orang).

Tabel 5. Persentase Ketuntasan Hasil Belajar sepak bola passing kaki bagiandalam pada Siklus II

\begin{tabular}{|c|c|c|c|c|c|c|c|}
\hline \multicolumn{2}{|r|}{ Sikap } & \multicolumn{2}{|c|}{ Pengetahuan } & \multicolumn{2}{|c|}{ Ketarampilan } & \multirow{2}{*}{$\begin{array}{l}\text { Jumlah } \\
\text { Siswa }\end{array}$} & \multirow[b]{2}{*}{ Ket } \\
\hline Skor & Predikat & Skor & Huruf & $\begin{array}{l}\text { Capain } \\
\text { Optimum }\end{array}$ & Huruf & & \\
\hline $90-100$ & $\begin{array}{l}\text { SB } \\
\text { (Sangat Baik) }\end{array}$ & $90-100$ & A & $90-100$ & A & 5 Siswa & $\begin{array}{l}13,89 \% \\
\text { Tuntas }\end{array}$ \\
\hline $78-89$ & $\begin{array}{l}\text { B } \\
\text { (Baik) }\end{array}$ & $78-89$ & B & 78-89 & B & $\begin{array}{l}22 \\
\text { Siswa }\end{array}$ & $\begin{array}{l}86,11 \% \\
\text { Tuntas }\end{array}$ \\
\hline $75-77$ & $\begin{array}{l}\text { C } \\
\text { (Cukup) }\end{array}$ & $75-77$ & $\mathrm{C}$ & $75-77$ & $\mathrm{C}$ & 5 Siswa & $\begin{array}{c}13,89 \% \\
\text { Tidak } \\
\text { Tuntas }\end{array}$ \\
\hline$<75$ & K & $<75$ & $\mathrm{D}$ & $<75$ & $\mathrm{D}$ & $\begin{array}{l}0 \\
\text { Siswa }\end{array}$ & $\begin{array}{c}0 \% \\
\text { Tidak } \\
\text { Tuntas }\end{array}$ \\
\hline
\end{tabular}

\section{Pembahasan}

Berdasarkan hasil analisis data dari implementasi model pembelajaran kooperatif tipe NHT yang bertujuan untuk meningkatkan aktivitas dan hasil belajar teknik dasar passing kaki bagian dalam, dimana hasil penelitian aktivitas belajar peserta didik pada siklus I terhadap pembelajaran PJOK khususnya pada materi teknik dasar passing kaki bagian dalam secara klasikal berada pada kategori cukup aktif. Dengan memperhatikan aktivitas dan hasil belajar teknik dasar passingkaki bagian dalam siklus I, peneliti melanjutkan ke siklus II dengan melihat permasalahan-permasalahan pada siklus I. Hal ini terbukti dari refleksi dari siklus I yang masih terdapat permasalahan-permasalahan dalam pelaksanaan tindakan.

Berdasarkan data analisa hasil uraian diatas, bahwa aktivitas dan hasil belajar meningkat dikarenakan:

1. Peserta didik lebih aktif dalam mengikuti suatu proses pembelajaran dalam melakukan interaksi dengan teman sehingga pembelajaran lebih aktif dan tidak satu arah.

2. Timbulnya kerjasama antar peserta didik dengan peserta didik, tim atau teman didalam kelompoknya dapat menyelesaikan tugas gerak yang diberikan oleh guru.

3. Peserta didik memiliki rasa tanggung jawab sehingga peserta didik dapat mengerjakan tugas dengan baik dalam suatu proses pembelajaran di dalam kelompoknya.

4. Peserta didik mengamati apa yang dicontohkan oleh guru atau dari orang lain dalam suatu proses pembelajaran.

5. Rasa percaya diri peserta didik dalam melaksanakan tugas gerak yang diberikan oleh guru.

Berdasarkan penelitian yang sudah dilakukan, adapun keterbatasan dalam melakukan penelitian ini yaitu: keterbatasan waktu pelaksanaan penelitian yang dilakukan 2 siklus, agar tidak mengganggu dari kurikulum sekolah yang sudah dibuat. Berdasarkan hasil penelitian yang telah peneliti lakukan serta teori-teori pendukung hasil penelitian yang telah dipaparkan di atas dapat

disimpulkan bahwa penerapan model pembelajaran kooperatif tipe NHT dapat meningkatkan aktivitas dan hasil belajar teknik dasar passing kaki bagian dalam pada peserta didik kelas X D AKL SMK Negeri 1 Singaraja Tahun Pelajaran 2018/2019.

Penelitian yang sudah dilaksanakan ini tidaklah selalu berjalan dengan lancar sesuai dengan yang diharapkan dan yang sudah direncanakan. Karena ada kendala- kendala yang dihadapi peneliti dalam menjalankan penelitian ini. Adapun kendala-kendala yang dihadapi adalah:

(a) jumlah alat-alat pendukung yang kurang dari jumlah kelompok belajar yang sudah direncanakan,

(b) respon peserta didik untuk memahami materi lambat sehingga harus dijelaskan berulang-ulang.

Dari kendala-kendala yang dihadapi tersebut adapun yang dilakukan peneliti untuk memecahkannya sehingga penelitian yang dilakukan dapat berjalan dengan lancar diantaranya adalah: (a) menggunakan lapangan sekolah yang sudah ada dan alat yang dimiliki oleh peserta didik, (b) menggunakan lantai aula untuk melakukan gerakan sikap lilin untuk kekurangan Matras, dan (c) menjelaskan kembali secara berulang- ulang materi yang belum dimengerti. 


\section{Simpulan}

Berdasarkan hasil analisis data dan pembahasan di atas dapat ditarik simpulan sebagai berikut.

1. Aktivitas belajar teknik dasar passing kaki bagian dalam meningkat melalui implementasi model pembelajaran kooperatif tipe NHT pada siswa kelas X D AKL SMK Negeri 1 Singaraja tahun pelajaran 2018/2019.

2. Hasil belajar teknik dasar passing kaki bagian dalam meningkat melalui implementasi model pembelajaran kooperatif tipe NHT pada siswa kelas X D AKL SMK Negeri 1 Singaraja tahun pelajaran $2018 / 2019$.

\section{Daftar Pustaka}

Aji, R. N. B. (2013) 'Nasionalisme Dalam Sepak Bola Indonesia Tahun 1950-1965 Sisi Sosial Dan Politik Sepak Bola', Lembaran Sejarah, 10(2), Pp. 135-148.

Atiq, A. And Selamet Budiyanto, K. (2020) 'Analisis Latihan Keterampilan Teknik Dasar Sepak Bola Untuk Atlet Pemula', Jurnal Pendidikan Jasmani Dan Olahraga, 4(1), Pp. 15-22. Available At: Https://Doi.Org/10.31539/Jpjo.V4i1.1482.

Budiman Agung (2018) 'COMPETITOR: Jurnal Pendidikan Kepelatihan Olahraga UPAYA PENINGKATAN TEKNIK PASSING BOLA DALAM', 10.

Hakim, M. A. A., Sunarto And Totalia, S. A. (2016) 'Penerapan Model Pembelajaran Problem Based Learning (PBL) Untuk Meningkatkan Hasil Belajar Peserta Didik Kelas XI IIS Dalam Mata Pelajaran Ekonomi Di SMAN 5 Surakarta Tahun Ajaran 2015/2016', Pendidikan Ekonomi, FKIP Universitas Sebelas Maret, 2(2), Pp. 1-13.

Hidayat, N. And Kusuma, G. (2013) 'Dari An Nasher Hingga Assyabaab: Peranan Etnis Arab Dalam Sepak Bola Di Surabaya Tahun 1930-1948', VERLEDEN Jurnal Kesejarahan, 3(1), Pp. 31-45. Available At: Http://Journal.Unair.Ac.Id/Dari-An-Nasher-Hingga-Assyabaab-Article-7805-Media-47-Category8.Html.

Prawira, R. Z. R. And Tribinuka, T. (2016) 'Pembinaan Pemain Muda Melalui Akademi Sepak Bola Rengga', Jurnal Sains Dan Seni Its, 5(2), Pp. 13-17.

Saleh, M. (2013) 'Strategi Pembelajaran Fiqh Dengan Problem-Based Learning', Jurnal Ilmiah Didaktika, 14(1), Pp. 190-220. Doi: 10.22373/Jid.V14i1.497.

Wiyasa, I. K. N. (2013) 'Model Pembelajaran Permainan Sepakbola', Model Pembelajaran Permainan Sepakbola Bagi Siswa Sekolah, 9(April), Pp. 1-10. 